\title{
Movimentos retóricos em produções escritas no exame Celpe-Bras
}

\author{
Regina Lúcia Péret Dell Isola \\ Natália Moreira Tosattib
}

\begin{abstract}
Resumo
Este artigo visa a apresentar resultado de pesquisa em que se investigou a execução de uma tarefa específica por meio da qual examinandos que prestaram o Celpe-Bras foram levados a comprovar seu nível de proficiência na variante brasileira da lingua portuguesa. Com base na teoria de Swales (1994, 1998) e na concepção de gênero como ação social, tal como propôs Bazerman (1994, 2005), foram analisadas 35 cartas do leitor produzidas pelos examinandos da segunda aplicação do exame Celpe-Bras no ano de 2008. Ao realizarem a tarefa IV que consistia em ler uma reportagem da revista "Istoé" e escrever um texto para ser publicado na seção de cartas do leitor da mesma revista, verificou-se diversidade de modos de produção discursiva. discursiva. Com a finalidade de avaliar a qualidade da produção escrita, foram analisados os movimentos retóricos de cada um dos textos produzidos e verificou-se o nível de conhecimento linguístico discursivo desses examinandos. Constatou-se que, na seção de contato, os examinandos optaram por diferentes formas de abertura em que se observa variedade de níveis de formalidade. No núcleo da carta, muitos optaram pela contextualização seguida de questionamento dos argumentos apresentados e da apresentação de ponto de vista favorável ao uso do telefone celular, em diferentes níveis de proficiência, mas houve uma preocupação geral em todas as cartas do nosso corpus em atender ao comando do enunciado da tarefa. Entretanto, na seção de fechamento, verificou-se que em 15 cartas os examinandos finalizaram com o encerramento, sem o desfecho. Dessas, constatamos que apenas em nove cartas cabia esse procedimento discursivo. Finalmente, em 20 cartas consta encerramento seguido de desfecho. Praticamente todas apresentaram problemas de coerência discursiva, tendo sido empregados diferentes níveis de formalidade entre a abertura e o desfecho. Em poucas cartas verificamos coerência entre os três movimentos retóricos, ou três seções (contato, núcleo e fechamento).
\end{abstract}

Palavras chave: escrita, gênero textual, retórica.

\footnotetext{
a Universidade Federal de Minas Gerais - reginadellisola@gmail.com

b Cefet-MG - natalia.tosatti@ig.com
} 


\section{Introdução}

O exame oficial brasileiro de proficiência em português para estrangeiros (Celpe-Bras) pauta-se em atividades sociointeracionistas avaliadas por meio de tarefas comunicativas. Tais tarefas são elaboradas à luz de um construto que entende proficiência como a capacidade de um indivíduo engajar-se em diferentes atividades no mundo, mostrando adequação às demandas dos vários contextos. Em outras palavras, proficiente é o examinando que faz "o uso adequado da língua para desempenhar ações no mundo" (Brasil, 2006 p. 4)

Para demonstrar essa capacidade, na Parte Escrita do Celpe-Bras, o examinando deve produzir quatro textos obedecendo às condições de produção exigidas para cada um deles, levando em conta determinados propósito, interlocutores, contextos e veículos de divulgação. Portanto, para um bom desempenho em determinadas tarefas do exame, o conhecimento sobre gêneros textuais é requisito fundamental.

Dell'Isola (2007) afirma que gêneros textuais são práticas sócio-históricas que se constituem como meios para agir sobre o mundo e dizer o mundo, constituindo-o de algum modo. Por serem fenômenos históricos, profundamente vinculados à vida cultural e social; fruto do trabalho coletivo; formas de ação social; modelos comunicativos; eventos textuais, os GTs apresentam características comunicativas, cognitivas, institucionais e linguísticas/estruturais, cuja finalidade é predizer e interpretar as ações humanas em qualquer contexto discursivo, além de ordenar e estabilizar as atividades comunicativas cotidianas. (DELL'ISOLA , 2007, p. 17).

Assim, os textos produzidos pelos examinandos não serão apenas formas, mas atividades submetidas a critérios de êxito.

A carta, por ser um gênero discursivo que ao longo da história tem servido de meio de comunicação para diferentes fins, é um gênero textual que vem sendo proposto com recorrência no exame. São diversas as ações discursivas que se podem realizar por meio de uma carta: solicitar, agradecer, reclamar, informar, cobrar, ameaçar são apenas alguns exemplos. Assim, de um modo geral, a carta é veículo de vários modos de interação: através dela as pessoas se apresentam, dão notícias a um familiar ou amigo, fazem petições, etc. Criada para mediar a 
distância entre dois indivíduos, a carta está ligada às relações sociais e apresenta-se de várias formas, dependendo da esfera discursiva e do objetivo de seu produtor.

A carta do leitor, foco de nossa análise, é um gênero que permite a um cidadão comum tornar público seu posicionamento a respeito de um tema. Esse leitor assume o papel de autor e, por meio dessa carta, tem o direito de opinar sobre os diferentes acontecimentos das esferas sociais podendo, assim, posicionar-se e atuar como sujeito de seu discurso.

Bezerra (2005) postula que a carta do leitor [...] é um texto utilizado em situação de ausência de contato imediato entre remetente e destinatário, que não se conhecem (o leitor e a equipe da revista/jornal, respectivamente), atendendo a diversos propósitos comunicativos: opinar, agradecer, reclamar, solicitar, elogiar, criticar, entre outros. É um gênero do domínio público, de caráter aberto, com o objetivo de divulgar seu conteúdo, possibilitando, assim, ao público geral a sua leitura. (Bezerra, 2005, p. 210).

Segundo o agrupamento de gêneros proposto por Schneuwly e Dolz (2004), a carta do leitor pertence à ordem do argumentar, situando-se na esfera de comunicação (domínio social) de assuntos/temas controversos. Para Costa (2008), a carta do leitor é um termômetro que afere o grau de sucesso dos artigos publicados nos jornais e revistas, pois os leitores escrevem reagindo, positiva ou negativamente, ao que leram; além de propiciar a interação entre leitor e jornal/revista, dando a estes uma ideia das expectativas daqueles em relação à linha editorial.

Segundo Koche et alli (2010), a carta do leitor permite aos leitores de um jornal ou revista manterem um diálogo com o responsável pela publicação ou por seções dela, ou, ainda, com os demais leitores. Por meio desse gênero, o leitor pode se manifestar em relação às matérias publicadas. Dell'Isola (2007, p. 74) afirma que a carta à redação "existe em função do leitor que por ela se manifesta, buscando atender suas intenções comunicativas. Não se destina a uma pessoa específica, mas a um público que tem acesso à carta veiculada."

Para se produzir uma carta do leitor é preciso ter a compreensão de como a linguagem se articula em ação veiculada através de texto escrito em uma determinada circunstância de 
interação; é necessário conhecer as principais determinações sócio-históricas e discursivas das cartas e considerar a variedade de possibilidades de organização textual desse gênero.

Na vida social contemporânea, carta do leitor tem merecido destaque entre os gêneros da esfera jornalística. Além de impor, a quem o redige, um modo de expressar que comprove a capacidade do locutor interagir de maneira crítica e participativa no mundo, a carta do leitor é uma prática discursiva usada como instrumento de intervenção na dinâmica social por produzir e negociar sentidos através da linguagem escrita, em contextos específicos.

Charaudeau (2008) defende que todo ato de linguagem realiza-se numa situação de comunicação que se define pelas respostas dadas a quatro perguntas básicas: 1) quando o sujeito se comunica, é para dizer o quê? Isso define a finalidade do ato de comunicação; 2) quem comunica com quem? Isso define a identidade dos parceiros do ato de comunicação; 3) o sujeito comunica-se para quê? Isso define o propósito do ato e; 4) em que circunstâncias o sujeito se comunica? Isso define as circunstâncias, as condições materiais e físicas do ato de comunicação.

De acordo com a abordagem comunicativa em que o exame Celpe-Bras se fundamenta, os gêneros são construções sociais que vinculam a produção da linguagem ao contexto sócio histórico em um momento de interlocução. Em função disso, as práticas (oral, escrita, auditiva, leitora) avaliadas nesse exame são contextualizadas em situações de comunicações propostas, mediadas por um gênero textual.

\section{O texto e a tarefa}

O texto que selecionamos para nossa análise foi proposto na Parte Escrita do Celpe-Bras aplicado no segundo semestre de 2012. A crônica "A morte do automóvel", de Affonso Romano de Sant'Anna, publicada no jornal Estado de Minas, compõe a Tarefa IV desse exame e serviu de instrumento para que os examinandos se posicionassem em relação ao ponto de vista adotado pelo cronista. A seguir, apresentamos o texto e a respectiva proposta de tarefa do exame. 


\section{AFFONSO ROMANO DE SANT'ANNA}

\section{A morte do automóvel}

Eu poderia começar narrando que outro dia peguei meu carro para ir a um evento e fui rodando, rodando, até que no meio do caminho me dei conta de que havia cometido um erro fatal: não deveria ter ido no meu carro, deveria ter pegado um táxi, pois não ia achar estacionamento.

Já que estava a caminho, continuei, cheguei ao lugar do compromisso, e, como previa, não havia jeito de estacionar. Fui olhando as ruas em torno, e nada. Acabei voltando para minha casa, botei o carro na garagem, peguei um táxi e fui ao compromisso.

Mas posso começar esta crônica de outro modo, dizendo: minhas amadas irmãs, meus amados irmãos! Tive uma visão! Como São João na Illa de Patmos, vi o Apocalipse! Eu vi a morte do automóvel! Esse veículo tão maravilhoso quanto desastroso vai morrer no século 21 !

Quando Henry Ford descobriu a linha de montagem e começou a produzir carros em série, foi uma revolução. $\mathrm{O}$ indivíduo se afirmava, cada um poderia ter a sua máquina. Isso foi (perversamente) estupendo.

O que veio depois é que se transformou num beco sem saída: qualquer cidade de tamanho médio conhece os desesperadores conges- tionamentos. Ficamos duas, três, quatro horas presos dentro dos carros.

Aí a engenharia de trânsito entra em cena: mudam a mão das ruas, criam pistas só para ônibus e táxis, inventam metrôs subterrâneos e de superficie.

Lamento informar que não adiantará. A quantidade de carros jogados nas ruas é maior do que nossa capacidade de abrir ruas, metrôs, etc.

O que fazer, já que a indústria automobilística gera (e degenera) centenas de produtos e move a sociedade de consumo?

Na verdade, lhes digo: tudo é provisório. Nossas cidades ainda estão cheias de estátuas de generais a cavalo. Mas os generais não andam mais a cavalo como antigamente, não são eles que comandam o mundo, são os industriais que comandam e estão a cavaleiro dos generais.

Outro dia, vi o engenheiro italiano que inventou o carro que vira helicóptero: cria asas, mas precisa de uma pista de 50 metros para decolar. Portanto, no engarrafamento não funciona. $\mathrm{E}$ as ambulâncias continuam buzinando atrás da gente para poderem passar.

Pois the afianço: o automóvel chegou ao fim da própria estrada. $\mathrm{O}$ desenvolvimento o liquidou. A solução será criada. Qual, não sei! Transporte coletivo? Qual? Redesenho das cidades? Não sei. Mas o automóvel está morto e não sabe. Ê um veículo individualista, poluidor e se prolifera como barata.

Poderia propor aqui, como naquele filme Um dia de fúria, que todos colocassem fogo nos seus carros ou os deixassem apodrecer nas garagens. Mas não devo fazer isso. Temo que um dia haverá engarrafamento tão amplo e total que todos os habitantes das cidades, encurralados, sem poder sair para frente ou para trás, sem poder se alimentar ou beber água, apodrecerão com seus veículos nas artérias enfartadas de nossas imensas e macabras cidades.

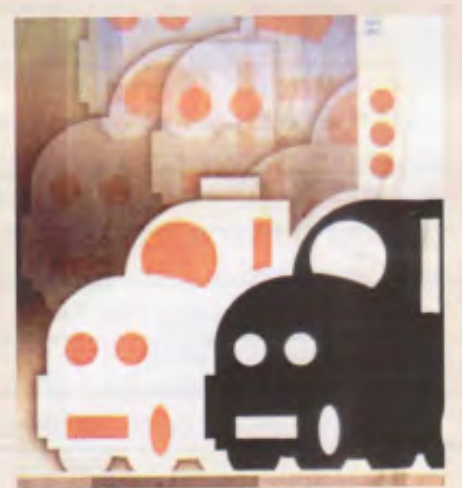

ESTADO DE MINAS, 17 jun. 2012 (adaptado),

Após ler a crônica abaixo, escreva uma carta para ser publicada na seção "Cartas do Leitor" do mesmo jornal, posicionando-se em relação ao ponto de vista do autor e avaliando a sobrevivência do automóvel no século 21. 
Solicitou-se que, por meio de uma carta do leitor, o examinando: 1) se posicionasse em relação ao ponto de vista do autor e 2) avaliasse a sobrevivência do automóvel no século 21. O comando da tarefa conduz o examinando a demonstrar domínio do gênero carta do leitor, posicionando-se como o leitor do jornal que se manifesta em relação a um determinado tema. Assim o examinando precisa compreender o "jogo avaliativo" e assumir a identidade que lhe foi atribuída nessa tarefa. Do ponto de vista de suas funções sociais, a carta do leitor funciona como um canal aberto que permite o contato entre mídia e os leitores, cumprindo o papel de tornar pública a voz do leitor.

Em linhas gerais, Affonso Romano de Sant'Anna, em sua crônica postula que:

- o automóvel tornou-se um mal;

- a quantidade de carros nas ruas é maior que a capacidade de se criar soluções para os congestionamentos;

- o automóvel é individualista e poluidor;

- o automóvel morrerá no século XXI.

Como se pode notar, o texto da tarefa traz ideias polêmicas para promover a discussão e motivarem a escrita da carta. Chamamos atenção para o fato de que o examinando teve liberdade em se posicionar, podendo, portanto, concordar, discordar ou discutir o ponto de vista do autor, ao cumprir o propósito comunicativo solicitado.

Swales (1990) apresenta três elementos necessários que, ao se interligarem, contribuem para que o propósito comunicativo de uma determinada manifestação discursiva seja realizado: comunidade discursiva, gênero e tarefa. $\mathrm{O}$ traço de união desses três elementos é o propósito comunicativo. A unidade básica da comunicação humana é o texto que pode ser definido como um conjunto de elementos linguísticos que detém caráter de totalidade comunicativa em função de fatores linguísticos, semânticos e pragmáticos.

Para Swales (1990), os gêneros textuais têm base em rituais comunicativos de um grupo de interactores, por ele definido como comunidade comunicativa. Os gêneros podem 
ser identificados a partir do objetivo que trazem explícita ou implicitamente, pela forma e pelo posicionamento. Já que, segundo esse autor, o gênero compreende uma classe de eventos comunicativos cujos exemplares compartilham os mesmos propósitos comunicativos. Esses propósitos são reconhecidos pela comunidade discursiva e constituem o conjunto de razões "que moldam a estrutura esquemática do discurso e influenciam e limitam a escolha de conteúdo e de estilo" (SWALES, 1990, p.58).

O conceito de gênero, tal como propôs Swales (1990), privilegia o caráter e o propósito comunicativo de uma situação, suas convenções e regras linguísticas e discursivas compartilhadas pela comunidade discursiva que convive, atua e interage em uma dada situação, dominando gêneros do discurso articulado e intencionado (a quem se destina: público-alvo) por ela mesma. Uma vez configuradas as expectativas, uma manifestação genérica pode ser considerada como prototípica pela comunidade geradora. Levantar uma manifestação textual (oral ou escrita) como um gênero, então, consiste em levantar as características socioculturais e linguísticas que regulam a forma, o conteúdo e as escolhas léxico-gramaticais que o compõem e que são desempenhadas por uma comunidade discursiva específica, identificada e descrita. Assim, as comunidades discursivas apresentam um conjunto de propósitos reconhecíveis e mecanismos de intercomunicação entre os seus membros, utilizando uma seleção de gêneros em evolução tanto para o avanço do conjunto de propósitos como para a legitimação dos mecanismos participativos que são essenciais no trabalho do professor voltado para o ensino da língua em uso.

Fundamentando na teoria de Swales (1990) sobre a organização retórica dos gêneros e na teoria de Bazerman (2005, 2006) sobre os sistemas de atividades e de gêneros, levantamos uma discussão relativa à produção de cartas do leitor escritas por examinandos ao Celpe-Bras.

A seguir apresentaremos a análise dos elementos que integram essas cartas quanto à natureza e à delimitação dos elementos que as constituem, levando em conta a esfera de uso da língua em que as cartas do leitor se realizam como atividades constitutivas de interação verbal. 


\section{Cartas dos examinandos ao Celpe-Bras: análise do discurso escrito}

Por ser um gênero que circula no contexto jornalístico, em seções específicas de revistas e jornais, apresenta uma estrutura básica que compreende a seção de contato, núcleo da carta e seção de despedida.

Entende-se por produção prototípica de uma carta do leitor o texto a ser publicado em uma seção específica de jornal ou revista. Na seção de abertura, espera-se que sejam apresentados o local e a data que indicam a cidade, o dia, o mês e o ano do envio da carta; além de apresentar o vocativo, que é a forma de tratamento empregada para se estabelecer o contato, sendo o tratamento condizente com o alocutário (ou receptor). No núcleo da carta ou corpo do texto, espera-se que haja a contextualização do assunto e que seja apresentada uma opinião. Na seção de fechamento, devem constar a despedida - manifestada com cordialidade - a saudação e a assinatura que é a identificação do locutor (remetente).

Conforme Dell'Isola (2014,p.157), ainda que esse gênero não possua uma estrutura rígida, em sua composição estão contidos alguns dados - alguns opcionais, outros, essenciais:

Seção de contato:

- local e data (opcional);

- abertura/vocativo (essencial);

Núcleo da carta:

- Contextualização/referência ao texto motivador (essencial);

\section{Corpo da carta:}

- Apresentação de posicionamento em relação ao ponto de vista do autor (essencial - exigência contida no comando da tarefa)

- Avaliação sobre a "sobrevivência do automóvel" (essencial - exigência contida no comando da tarefa)

Seção de fechamento:

- encerramento (essencial);

- despedida/desfecho (essencial);

- assinatura (opcional). 
Em relação ao registro, Bezerra (2005) defende que a carta do leitor é um gênero textual de fácil acesso e está escrito em registro formal ou semiformal do português, variando conforme o veículo de comunicação e o público a quem a carta se destina.

De acordo com a grade de correção elaborada pela Comissão Técnica do Exame, são elementos indispensáveis para a realização dessa tarefa: delimitação dos interlocutores - locutor (leitor do jornal) e alocutário (editor/autor/leitores do jornal); formato: carta do leitor; propósito comunicativo: posicionamento e avaliação.

A seguir, apresentamos as análises das 20 cartas que compõem o nosso corpus.

\section{Seção de contato}

Um dos elementos que compõe a abertura de uma carta é a indicação de local e data. Como as cartas de leitores recebidas pelos jornais e revistas passam por uma edição, normalmente essa datação não aparece nos textos publicados. Assim, em nossa análise, consideramos ser esse um elemento opcional.

Dos 20 vinte textos analisados, apenas 4 apresentaram essa informação.

Em relação ao registro, na seção de abertura houve a preferência pela formalidade: 11 cartas começaram fazendo uso dos vocativos "Prezado" ou "Senhor". Uma das cartas adota a semiformalidade na abertura, fazendo uso de "Caro". Foram dois os registros de informalidade: "Querido" e "Bom dia para vocês". Em seis dos textos analisados não houve seção de abertura, um dos examinandos atribuiu um título à carta e em cinco dos textos em análise o autor entrou no tema sem apresentar nenhum tipo de contextualização, negligenciado essa a característica do gênero que prevê tal seção de abertura.

É interessante observar que as cartas foram produzidas para receptores distintos:

1 Ressaltamos que, neste artigo, não fizemos nenhum ajuste ou correção nos trechos citados, extraídos das cartas produzidas pelos examinandos.
- ora para o cronista. Exemplos: Prezado Affonso Roamano de Sant"Anna.

- ora para o editor: Prezados editores

- ora diretamente para os leitores do jornal. Exemplos: Prezados (as) Leitores(as) da seção "cartas do leitor"

- ora sem explicitação. Exemplo: Prezados Senhor. 
OQuadro 1, a seguir, resume essas situações encontradas na seção de abertura dos textos em análise.

Quadro 1

\begin{tabular}{|c|c|c|c|c|c|c|}
\hline \multicolumn{7}{|c|}{ ABERTURA DAS CARTAS } \\
\hline & \multicolumn{4}{|c|}{ Receptor } & \multicolumn{2}{|c|}{ Sem receptor } \\
\hline $\begin{array}{c}\text { Grau de } \\
\text { formalidade }\end{array}$ & Autor & Editor & Leitor & $\begin{array}{c}\text { Sem destinatário } \\
\text { explícito }\end{array}$ & Título & $\begin{array}{c}\text { Nenhuma } \\
\text { Forma de } \\
\text { abertura }\end{array}$ \\
\hline Formal & $\begin{array}{c}\text { Senhor: } \\
\text { Affonso } \\
\text { Romano de } \\
\text { Santa' Anna } \\
\\
\\
\text { Prezado } \\
\text { Affonso } \\
\text { Romano } \\
\text { (2 } \\
\text { ocorrências) }\end{array}$ & $\begin{array}{l}\text { Prezados } \\
\text { editores }\end{array}$ & $\begin{array}{l}\text { Prezados } \\
\text { (as) } \\
\text { Leitores(as) } \\
\text { da seçãoo } \\
\text { "cartas do } \\
\text { leitor" }\end{array}$ & $\begin{array}{l}\text { - Prezado Jornal } \\
\text { "O Estado de } \\
\text { Minas" } \\
\text { - Prezados } \\
\text { (2 ocorrências) } \\
\text { - Prezados } \\
\text { senhores } \\
\text { - Prezado senhor } \\
\text { ou senhora }\end{array}$ & $\begin{array}{c}\text { "A } \\
\text { morte do } \\
\text { automóvel" }\end{array}$ & $\begin{array}{c}4 \\
\text { ocorrências }\end{array}$ \\
\hline Semiformal & Caro autor & & & $\begin{array}{l}\text { Em resposta ao } \\
\text { artigo "A morte } \\
\text { do automóvel" }\end{array}$ & & \\
\hline Informal & $\begin{array}{l}\text { Querido } \\
\text { Affonso }\end{array}$ & & & $\begin{array}{l}\text { Bom dia para } \\
\text { vocês }\end{array}$ & & \\
\hline
\end{tabular}

O texto que se inicia por um título, embora tenha "infringido" o gênero, recupera as características da carta já na primeira linha, ao mostrar que escreve a alguém a partir da leitura de um texto lido anteriormente, conforme observamos no trecho transcrito a seguir ${ }^{1}$. 
Exemplo 1

A morte do automóvel

Uma morte certa, eu duvido. Tenho certeza do mesmo jeito do autor que o automóvel torno-se um problema. As cidades não têm planejamento nem espaço para tantos automóveis, e como o autor disse "é um veículo individualista, poluidor e se prolifera como barata". Concordo a que foi uma invenção perversa.

O locutor da carta retoma o tema e os argumentos apresentados por Affonso Romano de Santa'Anna.

Nos quatro textos em que não houve a seção de abertura, observamos duas situações: uma em que houve referência ao texto-base, ficando claro para o leitor da seção carta do leitor que o texto foi motivado por uma leitura prévia, e outra em que não há a contextualização, ficando obscuro para o leitor da Seção Carta do Leitor o que teria motivado aquela manifestação.

Exemplo 2

Com muito prazer e um sorriso contínuo li o artigo sobre a morte do automóvel.

Exemplo 3

Devido a que cada dia a quantidade de caros nas ruas é maior por um consumo grande da nossa sociedade deles, nas nossas cidades tem acontecido engarrafamentos nas horas "pick" e também outro problema que tem surgido é você já não acha estacionamento, principalmente no centro da cidade; é por essa razão que pegar um táxi é mais conveniente ou a "melhor opção".

No exemplo 2, o autor da carta, embora tenha começado o texto sem nenhuma caracterização do gênero, deixa o leitor perceber que ele se dirige a um interlocutor determinado. Já no exemplo 3, ainda que o autor do texto retome argumentos presentes na crônica de Sant'Anna, não há nessa primeira parte do texto nenhum indício de que ele dialogue com um interlocutor.

\section{Núcleo da carta}

No núcleo da carta é que será executado o propósito de posicionamento e avaliação. Para que o provável leitor da Seção Carta do Leitor compreenda o propósito da carta proposta como tarefa, é preciso que o remetente dessa mensagem faça referência à crônica de Affonso Romano de Sant'Anna, 
deixando claro o posicionamento do cronista para, então, apresentar seu ponto de vista. Assim, entendemos como essencial a contextualização, fazendo referência à crônica de Affonso Romano de Sant'Anna.

Essa visão foi também compartilhada pelos examinandos. Dos 20 textos de nosso corpus, 18 retomaram o texto-base, como exemplificado a seguir.

\section{Exemplo 4}

Sou uma fiel leitora do seu jornal, e gosto especialmente das crônicas do espaço do jornal "Cultura". Durante o mês de junho o autor Affonso Romano de Sant'Anna publicou uma crônica sobre "A morte do automóvel" e aquele tema ficou dando volta na minha cabeça.

\section{Exemplo 5}

$\mathrm{Na}$ seguente carta escrevo meus acordos e desacordos referente ao artigo de Affonso Romano de Sant'Anna: "A morte do automóvel".

\section{Exemplo 6}

Depois de ler seu artigo fiquei com a sensação de que estamos perto do apocalipse, até me deu um pouco de medo, mas não posso deixar de concordar com você.

Nota-se nos exemplos transcritos acima a preocupação do locutor em localizar para seu leitor a motivação para a escrita da carta. Faz-se importante lembrar que na carta do leitor a mensagem é endereçada não só ao destinatário explicitado na seção de abertura, mas também a todos os leitores daquele veículo de informação.

No exemplo 1, verifica-se a construção do perfil do locutor: sabe-se que é uma pessoa do sexo feminino e leitora assídua do jornal, interessada, sobretudo, em temas sobre cultura. A construção dessa imagem confere à autora confiabilidade e até certa autoridade na escrita da carta, já que se coloca como "fiel leitora do seu jornal".

No exemplo 2, o autor da carta anuncia uma discussão frente às ideias presentes no texto lido, uma vez que ele apresentará os "acordos e desacordos" em relação ao texto de Affonso Romano de Sant'Anna. O terceiro exemplo revela um locutor 
crítico e bem-humorado que, ao afirmar que "Depois de ler seu artigo fiquei com a sensação de que estamos perto do apocalipse(...)", brinca com a situação caótica descrita pelo autor da crônica.

Ao demonstrarem tal cuidado em retomar o texto-base, os examinandos comprovam proficiência na situação comunicativa que lhes foi proposta.

Em sequência à contextualização, é esperado que o examinando (no papel de autor da carta) cumpra o comando a ele determinado: posicionar-se em relação ao ponto de vista do cronista e avaliar a sobrevivência do automóvel no século XXI.

Os textos analisados em nosso corpus revelam que os examinandos, em sua maioria, mostraram visão crítica em relação aos pontos de vista assumidos pelo cronista. Dos vinte textos analisados, 17 concordam com a ideia de que a mobilidade nos grandes centros é um grave problema e que o excesso de automóveis nas ruas contribui grandemente para o agravamento dessa situação. Apenas três examinandos defenderam o automóvel sem fazer ressalvas aos problemas por eles causados. Porém, ao avaliar a "sobrevivência dos automóveis no século 21", 12 examinandos não acreditam que o automóvel, embora seja um mal, vá "morrer" neste século. Outros três examinandos afirmam que o problema não são os automóveis, mas a sociedade individualista. Em cinco dos textos analisados encontramos concordância com o cronista na ideia de que o automóvel não sobreviverá.

A seguir transcrevemos alguns exemplos que ilustram esse movimento retórico.

\section{Exemplo 7}

É bom certo que cada dia é mais difícil movimentar-se nas cidades por causa
do congestionamento vial. Como diz Affonso Romano de Sant" Anna em "A
morte do automóvel, publicado por este jornal o domingo 17 de julho.
Mas também é certo que o automóvel presenta muitas vantagens para a gente.
É só saber quando é preciso de utilizar seu carro o quando é melhor ir de
ônibus.
No meu caso, mamãe com duas crianças pequenas, o automóvel faz minha vida
mais fácil a hora de transportar meus filhos para a escola.
(...)
Você, seu Affonso, imagina como poderia ser minha vida sem o carro e quanto
dinheiro gastaria movimentando minha família?




\section{Exemplo 8}

Eu penso, prezado Affonso, que o carro entrou em nossas entranhas e virou parte de nós, como uma virose que toma posse de você e nunca mais te deixa. (...) E como uma doença para a qual ainda não se tenha encontrado a cura, a doença pelo automóvel nos levará á morte. Ele, o automóveis irá sobreviver, e todos nós, portadores insanos de virose, seremos mortos pelas mesmas máquinas horrorosas que nós mesmos construímos, e que um dia nos tinha, dado a ilusão de poder alcançarmos por meio delas a liberdade!

Exemplo 9

Concordo com você que um dia vamos anunciar a morte do automóvel, mas isso não acontecerá logo como ser dito no artigo. Na minha opinião o que falta é mudança de estilo de vida. (...)

Nos trechos transcritos, verifica-se que os examinados assumiram posicionamento críticos esperados em cartas de leitores, cumprindo, assim, as exigências do enunciado da tarefa. Sendo a carta uma forma de mediar distância entre dois indivíduos, fornece um espaço de relação aberta que pode ser construído de muitas maneiras, outro aspecto a ser destacado foi a interlocução estabelecida entre locutor e alocutário. Os remetentes das cartas não se inibiram, por exemplo, em questionar e discutir os pontos levantados por Sant'Anna em sua crônica, estabelecendo diálogo direto com o autor e apresentado a eles outras situações que mostram a necessidade do uso do automóvel.

\section{Seção de fechamento}

A seção de fechamento compreende encerramento, despedida e assinatura. Todas as cartas apresentam encerramento, mas das 20 cartas, 12 não apresentam e despedida.

Em relação à estrutura formal do gênero "carta do leitor", podemos considerar que, quando dirigida aos editores da revista o desfecho é imprescindível, mas pode ser considerado dispensável, quando publicada em uma revista. Assim, cabe ao produtor do texto, levar em conta a situação discursiva da carta que escreve. Nas produções em que consta esse movimento retórico - o desfecho/despedida - espera-se a manutenção do nível de formalidade entre a forma de tratamento utilizada na abertura e a empregada nessa seção de fechamento da carta. Em relação à despedida, a formalidade foi mantida. 
As diferentes formas de despedida foram classificadas quanto ao nível de formalidade: Observa-se o uso de desfecho formal "Atenciosamente" (5 ocorrências), desfecho semiformal: "Obrigado", "Obrigado por sua atenção" e "Parabéns pelo artigo".

Em nenhuma das cartas analisadas houve ocorrência de informalidade na despedida.

Uma estratégia recorrente de desfecho nas cartas foi a proposição de alternativas ou medidas a serem adotadas para minimizar os problemas causados pelo excesso de tráfego. $\mathrm{O}$ uso de bicicletas, transportes públicos e proibição de circulação de veículos nos centros das cidades foram algumas das propostas. Também a criação de campanhas de conscientização foi sugerida.

\section{Proficiência e letramento}

A visão de proficiência do exame Celpe-Bras pressupõe letramento, que definimos como a capacidade de um indivíduo de se apropriar da escrita, sendo capaz de utilizá-la em diversas situações exigidas no cotidiano, compreender, usar e refletir sobre textos escritos tendo como meta cumprir um propósito comunicativo com vistas a participar de uma comunidade discursiva.

Assim, segundo o construto que orienta a avaliação dos textos produzidos no exame Celpe-Bras, um sujeito proficiente em língua estrangeira é capaz de compreender e produzir textos orais e escritos adequados às situações de comunicação em que atua; de posicionar-se criticamente diante do que lê ou ouve; de ler e escrever produzindo sentido em variadas situações.

Verificamos que, nas amostras de textos transcritos ao longo deste artigo, o trabalho com gêneros textuais colocou em evidência o nível de proficiência dos examinados na elaboração de uma carta do leitor, gênero que exige, primeiramente, a leitura crítica de um texto motivador para, em seguida, provocar uma manifestação em relação a esse texto.

É esperado que por meio da carta esse sujeito-examinando seja capaz de manifestar suas convicções, informar, persuadir, argumentar, posicionar-se, criticar. Enfim, é esperado que ele 
se mostre competente no uso da língua interagindo, por meio de textos, na situação de comunicação proposta.

A seguir, reproduzimos dois textos elaborados para a tarefa em análise. Nossa análise teve como foco o domínio do gênero carta do leitor e o cumprimento do propósito comunicado presente no enunciado. Não teceremos comentários sobre inadequações linguísticas ou influência de outras línguas nos textos analisados.

Texto 1

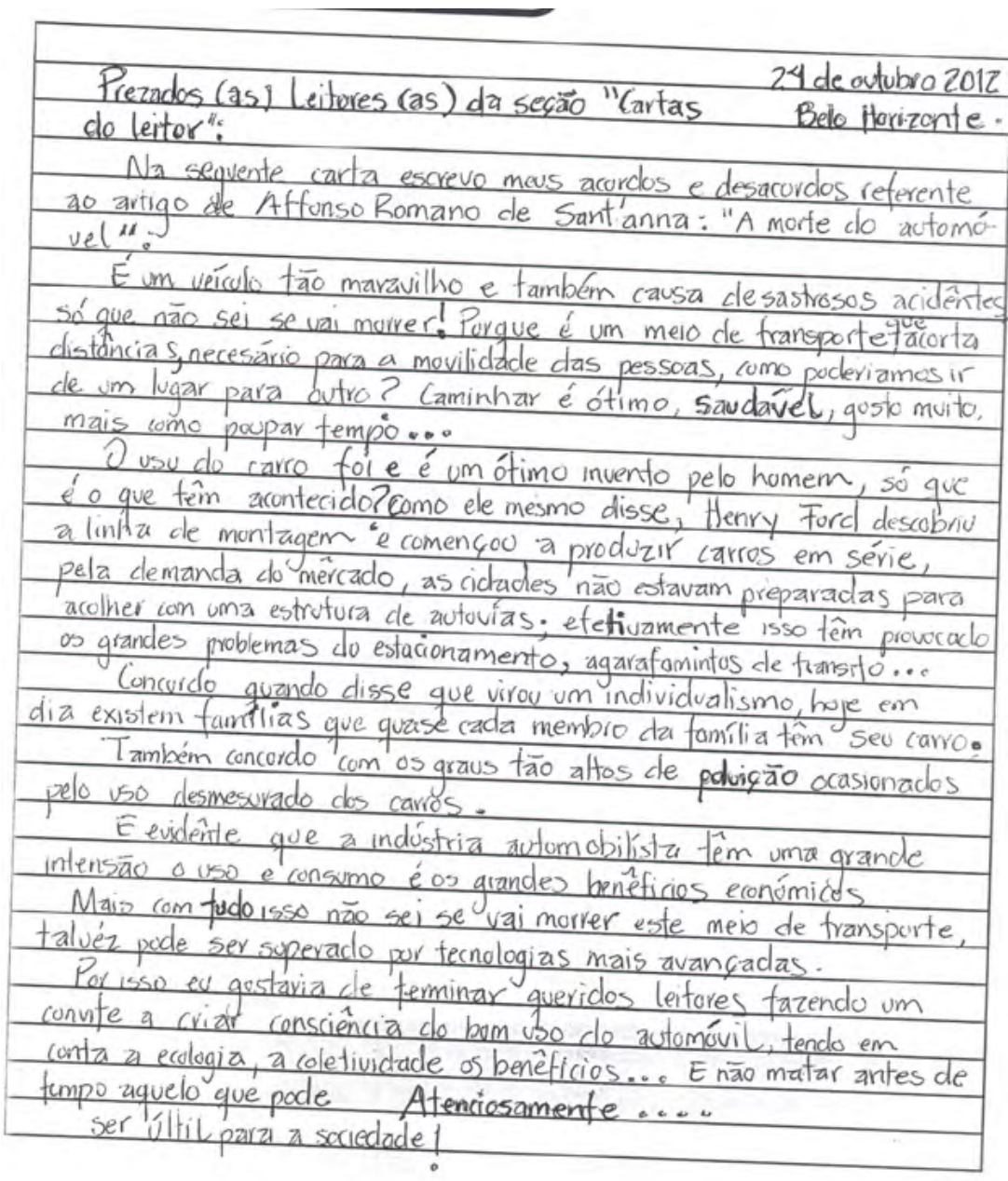

Nesse texto, observa-se que o examinado apresenta conhecimento sobre o gênero carta. A seção de abertura traz localização, data e, de maneira, formal, há o endereçamento 
da mensagem aos leitores do jornal. Em seguida, foi feita a retomada do texto base e apresentada a motivação da escrita: apresentar acordos desacordos em relação ao texto de Affonso Romano de Sant'Anna. No corpo do texto, o autor da carta retoma alguns argumentos de Sant'Anna para apresentar seu ponto de vista. Esse leitor crítico, logo no início de sua carta, coloca em dúvida a afirmação de que o automóvel não sobreviverá ao século 21. "É um veículo tão maravilhoso e também causa desastrosos acidentes, só que não sei se vai morrer!".

Na sequência é feita uma discussão em relação aos pontos levantados pelo autor. Na seção de fechamento, rompendo-se a formalidade da distância estabelecida pelo uso do vocativo "Prezados" empregado na abertura da carta, o autor se aproxima dos leitores dirigindo-se a eles como "queridos leitores" para convidá-los a "criar consciência do bom uso do automóvel". Por fim, ele se despede "Atenciosamente".

A quebra da formalidade no final do texto, embora seja um problema de coerência em relação à abertura do texto, não compromete a qualidade do cumprimento do propósito. Esse texto revela um sujeito que foi capaz de fazer uma leitura crítica do texto-base, manifestando suas opiniões e ainda apresentando uma preocupação cidadã ao, na conclusão, chamar atenção para a responsabilidade social.

No texto 2 verificaremos um outro estágio de proficiência.

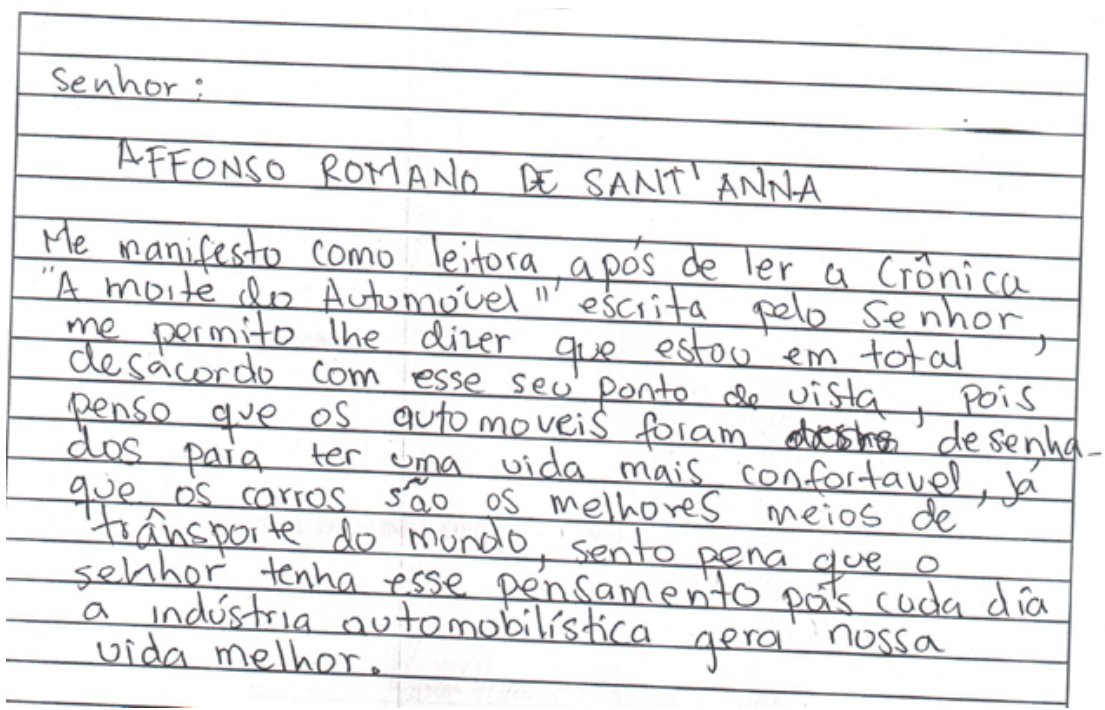


Nesse segundo texto, notamos que o examinando tem conhecimento sobre o gênero carta do leitor, uma vez que se preocupa dirigir-se a um interlocutor, no caso o próprio autor da crônica, e faz referência explícita ao texto motivador. Porém, ele ignora os demais leitores, uma vez que não se preocupara em resumir para um provável leitor da "Seção dos leitores" o ponto de vista assumido pelo cronista. Assim a realização do propósito comunicativo se dá de uma forma menos eficiente.

A noção de nível de proficiência em português como língua estrangeira evoca a ideia de gradações em uma escala contínua onde se é possível conceber desde um nível zero, ou seja, o total desconhecimento da língua, até níveis de competência que se aproximam aos de um falante nativo fluente e escolarizado. Entre as propostas de avaliação da proficiência, o exame Celpe-Bras está orientado para o estabelecimento de medidas que visem a verificar o que o examinando é capaz de compor com o seu conhecimento da variante brasileira da língua portuguesa. Desse modo, focaliza-se o desempenho dos examinandos de acordo com a maneira pela qual eles utilizam seu conhecimento de português e suas habilidades de expressão oral e escrita nessa língua. Tais habilidades são testadas de acordo com os parâmetros de um usuário falante nativo.

\section{Considerações finais}

A leitura e a produção de textos de gêneros diversos dizem muito sobre a proficiência linguística e, consequentemente, sobre o letramento do produtor desses textos. Um escritor competente deve, portanto, provar que sabe se comunicar de forma articulada e crítica por meio de gêneros diversos, cumprindo objetivos, adequando seu discurso, realizando, assim, ações comunicativas.

É importante que os examinandos do Celpe-Bras considerem a diversidade de situações comunicativas em que se observa a orientação para a informação, com o fim de se levantar o seu sentido como função, ou finalidade que, associado ao objetivo, confere, em parte, especificidade à organização da ação verbal na interação linguística.

Neste artigo, com base na Linguística do Texto e do Discurso, buscamos analisar 20 cartas do leitor produzidas pelos examinandos ao Celpe-Bras, ao realizarem a Tarefa IV da 
segunda aplicação do exame no ano de 2012. Verificamos que, para demonstrar a habilidade de leitura e produção escrita, não basta ao examinando ler a crônica publicada no jornal Estado de Minas e escrever um texto. É necessário que ele leve em conta que o texto a ser produzido tem o propósito de ser publicado na seção de cartas do leitor do mesmo jornal. Considerando o gênero uma ação social, é preciso que o examinando saiba que, para redigir uma carta do leitor, além dos elementos indispensáveis da situação discursiva há que se considerar os movimentos retóricos desse gênero.

\section{REFERÊNCIAS}

BAZERMAN, C. Gêneros textuais, tipificação e interação. São Paulo: Cortez, 2005.

. Gênero, agência e escrita. São Paulo: Cortez, 2006. p.9-43.

BEZERRA, M.A. Por que cartas de leitor na sala de aula? In: DIONISIO, A. P., MACHADO. A. R., BEZERRA, M. A (org.). Gêneros textuais e ensino. 3.ed Rio de Janeiro: Lucerna, 2005. p. 208-216.

CHARAUDEAU, Patrick. Linguagem e discurso: modos de organização. São Paulo: Contexto, 2008. p.249.

COSTA, S. D. Cartas de leitores: gênero discursivo porta-voz de queixa, crítica e denúncia no jornal O Dia. In: Soletras - Revista do Departamento de Letras da UERJ - n 10, 2005, p.28-41. Disponível em: <http://www.filologia.org.br/soletras/10/03.htm>. Acesso em 17 de maio de 2008.

DELL'ISOLA, Regina L. P. Retextualização de gêneros escritos. Rio de Janeiro: Lucerna, 2007.

(Org.) O exame Celpe-Bras em foco. Campinas: Pontes, 2014.

KOCHE, Vanilda Salton, BOFF, Odete Maria Benetti, MARINELLO, Adiane Fogali. Leitura e produção textual: gêneros textuais do argumentar e do expor. Petrópolis: Vozes, 2010.

SCHNEUWLY, B.; DOLZ, J. Gêneros orais e escritos na escola. Trad. Roxane Rojo e Glaís Sales Cordeiro. São Paulo: Mercado de Letras, 2004, p. 95-128.

SWALES, J. Genre analysis: English in academic and research settings. Cambridge: Cambridge University Press, 1990 pp.1-65. 


\section{Abstract \\ Rhetorical movements in written productions on the Celpe-Bras exam}

In this article we will present the research result in which it was investigated the execution of a specific task by examinees taking Celpe-Bras who were being tested to prove their proficiency level in Brazilian Portuguese. Based on Swales's theory $(1994,1998)$ and in the genre conception as a social action proposed by Bazerman (1994, 2005), readers' letters produced by the examinees taking Celpe-Bras were analyzed. When performing task $I V$, which consisted of reading a report from a Brazilian periodical and writing a text to be published in the readers' letters section of the same medium, it was observed a diversity in the discursive written production. Aiming at assessing the quality of the written production, the rhetorical movements of each text produced were analyzed and these examinees' level of discursive linguistic knowledge was assessed. It was noted that, in the heading section, the examinees opted for different ways of opening the letter in which a variety of formality levels is observed. In the development of the letter, many opted for contextualizing followed by questioning the arguments presented in the basetext and defending a point of view. Even presenting different levels of proficiency, there was great concern in all the letters in our corpus to answer the command in the task heading. However, in the closing section, it was noted that in many letters the examinees ended their texts without presenting a proper closing as it would be expected in this genre. Practically all the productions presented problems with discursive coherence, having different levels of formality been used in the heading and closing. It was checked, in only a few letters, coherence in the three rhetorical movements, or three sections (heading, development and closing).

Key words: writing, textual genre, rhetoric. 